\title{
GEN REGULASI TANAMAN LOKAL INDONESIA: IMUNOMODULATOR COVID-19
}

\author{
Isna Rasdianah Aziz*, Devi Armita, Hajrah, Kurnia Makmur \\ Jurusan Biologi \\ Fakultas Sains dan Teknologi UIN Alauddin Makassar \\ Jl. Sultan Alauddin No. 63, Kabupaten Gowa, Sulawesi Selatan. 92113 \\ *E-mail: isna-rasdianah@uin-alauddin.ac.id
}

\begin{abstract}
Abstrak: Pandemi COVID-19 yang melanda seluruh dunia pada akhir tahun 2019 meresahkan semua kalangan. Di tengah kekhawatiran tersebut, pada peneliti terus mengembangkan vaksin dan obat-obatan untuk memerangi serangan virus SARS-CoV-2 tersebut. Tak terkecuali, tanaman lokal berbagai Negara, termasuk Indonesia yang diyakini mampu memberi sumbangsih perbaikan imun sebagai upaya pencegahan dan pertahanan imun. Tanaman lokal mampu berperan sebagai imunomodulator karena kapabilitasnya menghasilkan senyawa bioaktif tertentu. Regulasi ekspresi gen berperan langsung pada biosintesis senyawa bioaktif dalam tanaman lokal tersebut.
\end{abstract}

Kata Kunci: COVID-19, herbal, pandemik, SARS-CoV-2, tanaman obat

\section{PENDAHULUAN}

$\mathrm{T}$

anaman lokal Indonesia tak sedikit memberi peran di era pandemi COVID-19. Tanaman tersebut sebagian besar adalah tanaman asli yang hanya tumbuh di tanah Indonesia. Dan sebagian lagi adalah tanaman introduksi yang dibawa dari luar negeri untuk dapat ditumbuhkan dan dikembangkan di Indonesia. Sebanyak 660 spesies tanaman lokal Indonesia dimanfaatkan sebagai tanaman obat dalam memerangi penyakit terkait virus, termasuk SARS-CoV-2 (Ristoja, 2020). Material genetik yang dimiliki oleh tanaman lokal tersebut, baik pada nukleus, mitokondria dan sitoplasma memiliki peran dasar dalam menentukan struktur dan sifat suatu sel. Kromosom salah satunya, bertanggungjawab pada pemisahan DNA dalam jumlah yang sama dan memastikan bahwa keturunan membawa sifat dari kedua orang tua pada setiap pembelahan sel (Bass \& Birchler, 2011). Di samping itu, kromosom juga menjaga integritas dan ketepatan replikasi genom pada setiap siklus sel. Kromosom memiliki tiga elemen struktur utama yang diperlukan untuk replikasi dan pemeliharaan: sentromer, telomer dan unit replikasi. Struktur kromosom membantu memastikan DNA tetap melilit pada protein. Material genetik ini merupakan sumber daya genetik yang memiliki nilai potensial dan berperan dalam peningkatan kesehatan masyarakat.

Selain kaitan langsung dengan materi genetik, tanaman lokal dilengkapi dengan senyawa bioaktif, kandungan polifenol dan aktivitas antioksidan yang bervariasi (Issa et al., 2006). Flavonoid memiliki sifat biologis yang luas yang meningkatkan kesehatan manusia dan membantu mengurangi risiko penyakit dengan perannya memperluas aktivitas vitamin $\mathrm{C}$, bertindak sebagai antioksidan, melindungi kolesterol LDL dari oksidasi, menghambat agregasi platelet, dan bertindak sebagai agen antiinflamasi, antitumor dan antivirus.

Bahan yang dapat memodulasi sistem imun tubuh, mengaktifkan mekanisme 
pertahanan alamiah maupun adaptif yang dapat mengembalikan ketidakseimbangan sistem imun yang terganggu dikenal sebagai imunomodulator. Tubuh dalam melindungi diri dari serangan mikroorganisme patogen termasuk virus penyebab COVID-19 melalui sistem modulasi tersebut. Sistem pertahanan tubuh dapat diaktifkan dengan memberikan imunomodulator yang dapat digunakan untuk meningkatkan respon imun seseorang (Wulan \& Agusni, 2015). Imunomodulator terdiri dari imunostimulator, imunorestorator, dan imunosupresor. Secara klinis imunomodulator digunakan pada pasien dengan gangguan imunitas, antara lain pada kasus keganasan, HIV/AIDS, malnutrisi, alergi, termasuk di antaranya akibat infeksi oleh virus penyebab COVID-19. Imunomodulator dengan berbahan tanaman lokal Indonesia terus dikembangkan oleh para ahli dalam rangka pencegahan infeksi SARS-CoV-2 (PDPOTJI, 2020). Uji klinis fase I dua kandidat imunomodulator herbal dari tanaman lokal Indonesia telah dilakukan oleh tim LIPI pada pasien COVID-19 di Wisma Atlet Kemayoran, Jakarta di awal Agustus 2020.

Adapun beberapa tanaman lokal Indonesia yang dimanfaatkan sebagai imunomodulator dalam penanganan COVID-19 dipaparkan pada tabel 1.

Tabel 1. Tanaman lokal Indonesia (wild type \& introduksi) yang dimanfaatkan dalam penanganan COVID19 sebagai imunomodulator dan sebarannya di Indonesia

\begin{tabular}{|c|c|c|c|c|}
\hline No. & Spesies & Genus & Nama lokal & Lokasi \\
\hline \multirow[t]{2}{*}{1} & Allium sativum & Allium & Bawang putih & $\begin{array}{l}\text { Sumatera, Jawa, } \\
\text { Kalimantan, Sulawesi, Nusa }\end{array}$ \\
\hline & & & & $\begin{array}{l}\text { Tenggara, Bali, Maluku, } \\
\text { Papua }\end{array}$ \\
\hline 2 & $\begin{array}{l}\text { Andrographis } \\
\text { paniculata }\end{array}$ & Andrographis & Sambiloto & $\begin{array}{l}\text { Sumatera, Jawa, } \\
\text { Kalimantan, Sulawesi, Nusa } \\
\text { Tenggara, Bali, Papua }\end{array}$ \\
\hline 3 & Blumea balsamifera & Blumea & Sembung & $\begin{array}{l}\text { Sumatera, Jawa, Sulawesi } \\
\text { utara, Bali }\end{array}$ \\
\hline 4 & Cinnamomum verum & Cinnamomum & Kayu manis & $\begin{array}{ll}\text { Sumatera Barat, } & \text { Jambi, } \\
\text { Jawa, Kalimantan } & \text { Selatan, } \\
\text { Sulawesi Utara, } & \text { Maluku } \\
\text { Utara } & \end{array}$ \\
\hline 5 & Citrus sinensis & Citrus & Jeruk manis & $\begin{array}{l}\text { Maluku, Jawa Timur, } \\
\text { Sumatera Utara }\end{array}$ \\
\hline 6 & Cordyceps militaris & Cordyceps & Jamur cordyceps & $\begin{array}{l}\text { Jakarta, Jawa (Introduksi } \\
\text { dari Himalaya dan Tibet) }\end{array}$ \\
\hline \multirow[t]{2}{*}{7} & Curcuma longa & Curcuma & Kunyit & $\begin{array}{l}\text { Sumatera, Jawa, } \\
\text { Kalimantan, Sulawesi, Nusa }\end{array}$ \\
\hline & & & & $\begin{array}{l}\text { Tenggara, Bali, Maluku, } \\
\text { Papua }\end{array}$ \\
\hline \multirow[t]{2}{*}{8} & $\begin{array}{l}\text { Curcuma } \\
\text { zanthorrhiza }\end{array}$ & Curcuma & Temulawak & $\begin{array}{l}\text { Sumatera, Jawa, } \\
\text { Kalimantan, Sulawesi, Nusa }\end{array}$ \\
\hline & & & & $\begin{array}{l}\text { Tenggara, Bali, Maluku, } \\
\text { Papua }\end{array}$ \\
\hline \multirow[t]{2}{*}{9} & Cymbopogon citratus & Cymbopogon & Sereh; Serai & $\begin{array}{l}\text { Sumatera, Jawa, } \\
\text { Kalimantan, Sulawesi, Nusa }\end{array}$ \\
\hline & & & & $\begin{array}{l}\text { Tenggara, Bali, Maluku, } \\
\text { Papua }\end{array}$ \\
\hline \multirow[t]{2}{*}{10} & Kaempferia galanga & Kaempferia & Kencur & $\begin{array}{l}\text { Sumatera, Jawa, } \\
\text { Kalimantan, Sulawesi, Nusa }\end{array}$ \\
\hline & & & & $\begin{array}{l}\text { Tenggara, Bali, Maluku, } \\
\text { Papua }\end{array}$ \\
\hline
\end{tabular}




\begin{tabular}{|c|c|c|c|c|}
\hline 11 & Moringa oleifera & Moringa & Kelor & $\begin{array}{l}\text { Sumatera, Jawa, } \\
\text { Kalimantan, Sulawesi, Nusa } \\
\text { Tenggara, Bali, Maluku }\end{array}$ \\
\hline 12 & Nigella sativa & Nigella & Jintan hitam & $\begin{array}{l}\text { Sumatera Utara, Jawa, } \\
\text { Sulawesi Selatan }\end{array}$ \\
\hline 13 & Phyllantus niruri & Phyllantus & Meniran hijau & $\begin{array}{l}\text { Sumatera, Jawa, } \\
\text { Kalimantan, Sulawesi, Nusa } \\
\text { Tenggara, Bali, Maluku, } \\
\text { Papua }\end{array}$ \\
\hline 14 & Phyllanthus urinaria & Phyllanthus & Meniran merah & $\begin{array}{l}\text { Sumatera, Jawa, } \\
\text { Kalimantan, Sulawesi, Nusa } \\
\text { Tenggara, Bali, Maluku, } \\
\text { Papua }\end{array}$ \\
\hline 15 & Psidium guajava & Psidium & Jambu biji & $\begin{array}{l}\text { Sumatera, Jawa, } \\
\text { Kalimantan, Sulawesi, Nusa } \\
\text { Tenggara, Bali, Maluku, } \\
\text { Papua }\end{array}$ \\
\hline 16 & Syzygium aromaticum & Syzygium & Cengkeh & $\begin{array}{l}\text { Sumatera, Jawa, } \\
\text { Kalimantan, Sulawesi, Nusa } \\
\text { Tenggara, Bali, Maluku, } \\
\text { Papua }\end{array}$ \\
\hline 17 & Syzygium polyanthum & Syzygium & Salam & $\begin{array}{l}\text { Sumatera, Jawa, } \\
\text { Kalimantan, Sulawesi, Nusa } \\
\text { Tenggara, Bali, Maluku }\end{array}$ \\
\hline 18 & Zingiber officinale & Zingiber & Jahe & $\begin{array}{l}\text { Sumatera, Jawa, } \\
\text { Kalimantan, Sulawesi, Nusa } \\
\text { Tenggara, Bali, Maluku, } \\
\text { Papua }\end{array}$ \\
\hline
\end{tabular}

\section{TANAMAN LOKAL SEBAGAI IMUNOMODULATOR}



Gambar 1. Mekanisme aksi tanaman lokal yang diformulasi sebagai imunomodulator pada target SARS-CoV-2 (Vellingiri et al., 2020)

Sistem pengobatan menggunakan obat herbal lokal merupakan pengobatan tertua 
dalam sejarah manusia (Ravishankar dan Shukla, 2007). Formulasi tunggal mengandung banyak konstituen fitokimia yang berfungsi sendiri atau dalam kombinasi dengan senyawa lain untuk menghasilkan efek farmakologis yang diinginkan (Parasuraman et al., 2014). Efek antivirus dari tanaman obat telah memainkan peran yang luar biasa pada berbagai tahap pertumbuhan virus (Akram et al., 2018). Manfaat menggunakan ramuan tanaman obat ini pada infeksi saluran pernapasan akibat virus adalah untuk membangun stimulasi kekebalan dan efek modulasi peradangan untuk mengelola sistem kekebalan.

HCoV umumnya adalah kelompok virus RNA jenis positive-sense single-stranded $30.000 \mathrm{bp}$. Dua kelompok protein menjadi ciri $\mathrm{HCoV}$ yaitu protein struktural, dan protein non-struktural seperti RNA polimerase (RdRp) (nsp12) (Elfiky, 2020). Coronavirus seperti SARS dan MERS memiliki kemampuan menghindari deteksi kekebalan dan meredam respons kekebalan. Selama infeksi virus, faktor inang memunculkan respons imun terhadap virus (Gambar 1). Sel T, terutama CD4 + dan CD8 + memainkan peran antivirus yang signifikan untuk memerangi patogen dan meningkatkan risiko pengembangan autoimunitas/peradangan (Cecere et al., 2012). Sel CD4 + T meningkatkan produksi antibodi spesifik virus dengan mengaktifkan sel $\mathrm{B}$ yang bergantung pada sel $\mathrm{T}$. Akan tetapi, sel CD8 $+\mathrm{T}$ bersifat sitotoksik dan membunuh sel yang terinfeksi virus. Sel CD8 + T menyumbang sekitar $80 \%$ dari total sel inflamasi di interstitium paru pada pasien yang terinfeksi SARS-CoV dan memainkan peran penting dalam membersihkan virus korona pada sel yang terinfeksi dan menyebabkan cedera kekebalan (Maloir et al., 2018). Selain itu, sel T helper membuat sitokin proinflamasi melalui pensinyalan NF-kB (Manni et al., 2014). Sitokin, IL-17 merekrut monosit dan neutrofil ke tempat infeksi yang menunjukkan peradangan dan mengaktifkan kaskade hilir sitokin dan kemokin lainnya, termasuk IL-1, IL-6, IL-8, IL-21, TNF- $\beta$, dan MCP- 1 (Bunte dan Beikler, 2019). Apoptosis sel T diinduksi oleh daerah mirip BH3 yang terletak di domain sitosol C-terminal dari protein SARS-CoV yang dimediasi oleh BclxL (Yang et al., 2005). Dari bukti eksperimental ditunjukkan bahwa respon sel T terhadap protein $\mathrm{S}$ dan protein struktural lainnya (termasuk protein $\mathrm{M}$ dan $\mathrm{N}$ ) tahan lama, persisten dan memberikan bukti untuk merancang obat dan vaksin baru untuk SARS-CoV-2 yang terdiri dari virus. protein struktural, yang dapat menyebabkan respons sel memori yang dominan, efektif, dan jangka panjang terhadap virus. Namun, penelitian sebelumnya juga melaporkan peran penting sel T CD8 + dan CD4 + dalam pembersihan SARS-CoV (Chen et al., 2010), sementara Janice Oh et al. (2012) juga mengamati bahwa pengembangan antibodi penetralisir spesifik SARS-CoV membutuhkan sel pembantu CD4 + T. Selain itu, protein ACE2 yang menyatu dengan domain human immunoglobulin G Fc (ACE2Fc) pasien SARS-CoV-2 mungkin memiliki manfaat dari antibodi penetralisir tradisional yang dapat digunakan sebagai pengobatan untuk infeksi. Pada akhirnya, akan ada kebutuhan untuk uji klinis untuk menggambarkan efek samping tertentu dari pengobatan ACE2-Fc (Kruse, 2020). Oleh karena itu ACE2-Fc mungkin memainkan peran penting dalam pengobatan SARS-CoV-2, jika fungsi ACE2-Fc dihambat (Kruse, 2020). Studi imunologi ini menunjukkan betapa pentingnya memahami dasar-dasar tanggapan kekebalan pada virus ini, sehingga sel kekebalan ini dapat diinduksi untuk menyerang lebih lanjut virus dengan peningkatan spesifisitas. Pengobatan yang dimediasi oleh tanaman lokal/herbal dengan kemampuannya dianggap mampu memperkuat daya tahan tubuh dan mengurangi faktor patogen virus (Zhou et al., 2020).

\section{GEN REGULASI TANAMAN LOKAL INDONESIA}

Kromosom merupakan struktur nukleoprotein yang membawa materi genetik dan 
membawa informasi untuk aktivitas regulasi sel (Crow \& Crow, 2002; Francis, 2007). Jika diamati di bawah mikroskop, jumlah kromosom pada tanaman berbunga cukup banyak. Kromosom pada tumbuhan memiliki variasi sebanyak jumlah spesies yang ada, dapat berbeda dari satu spesies dengan spesies lainnya dan dapat berbeda antara tipe wild (liar) dan kultivar (Aziz, 2019; Aziz, 2020). Kromosom berfungsi membawa sifat individu dan membawa informasi genetik, karena di dalam kromosom mengandung gen. Regulasi ekspresi gen berperan langsung pada biosintesis senyawa bioaktif dalam tanaman.

Metabolit sekunder tumbuhan terdiri dari kelompok senyawa heterogen. Berbasis pada asal biosintesis, metabolit sekunder tumbuhan diklasifikasikan menjadi terpenoid, alkaloid, fenilpropanoid dan senyawa fenolik, seperti flavonoid. Fungsi flavonoid biologis terkait dengan potensi sitotoksisitas dan kapasitasnya untuk dapat dilakukan oleh enzim melalui kompleksasi protein. Beberapa flavonoid memberikan perlindungan stres, misalnya, bertindak sebagai scavenger terhadap radikal bebas seperti ROS. Flavonoid terbentuk secara alami pada tumbuhan. Pada kingdom tumbuhan, jalur biosintetik flavonoid dapat menghasilkan berbagai senyawa berpigmen maupun non-pigmentasi. Senyawa flavonoid telah terlibat dalam beberapa proses biologis dan beberapa fungsinya bagi kesehatan manusia, termasuk sebagai imunomodulator. Pigmen flavonoid telah digunakan sebagai penanda yang mudah terlihat dalam percobaan genetika molekuler dan untuk regulasi ekspresi gen (Koes et al., 2005). Biosintesis flavonoid terjadi melalui jalur fenilpropanoid, dan tergantung pada konstitusi genetik tanaman yang dapat memiliki perbedaan pada pembentukan flavonoid metabolit yang meliputi antosianin, flavon, dan antosianidin (Winkel-Shirley, 2001a, 2001b; Schijlen et al., 2004). Ekspresi gen dan regulasi telah ditingkatkan dengan menargetkan gen struktural serta regulasi itu diperlukan untuk biosintesis flavonoid berpigmen ini.

Tabel 2. Gen-gen yang terlibat dalam regulasi genetik biosintesis senyawa aktif pada tanaman lokal Indonesia

\begin{tabular}{|c|c|c|c|c|c|}
\hline No. & Spesies & Nama Lokal & Gen & Fungsi & Referensi \\
\hline \multirow[t]{9}{*}{1} & \multirow[t]{9}{*}{ Allium sativum } & \multirow[t]{9}{*}{ Bawang putih } & SG6 & aktivasi antosianin & $\begin{array}{l}\text { Schwinn et al., } \\
2016\end{array}$ \\
\hline & & & MYB1 & aktivasi antosianin & $\begin{array}{l}\text { Schwinn et al., } \\
2016\end{array}$ \\
\hline & & & SG7 & produksi flavonol & $\begin{array}{l}\text { Schwinn et al., } \\
2016\end{array}$ \\
\hline & & & MYB29 & produksi flavonol & $\begin{array}{l}\text { Schwinn et al., } \\
2016\end{array}$ \\
\hline & & & SG4 & $\begin{array}{l}\text { menekan } \\
\text { fenilpropanoid dan } \\
\text { sintesis flavonoid }\end{array}$ & $\begin{array}{l}\text { Schwinn et al., } \\
2016\end{array}$ \\
\hline & & & MYB4 & $\begin{array}{l}\text { menekan } \\
\text { fenilpropanoid dan } \\
\text { sintesis flavonoid }\end{array}$ & $\begin{array}{l}\text { Schwinn et al., } \\
2016\end{array}$ \\
\hline & & & MYB5 & $\begin{array}{l}\text { menekan } \\
\text { fenilpropanoid dan } \\
\text { sintesis flavonoid }\end{array}$ & $\begin{array}{l}\text { Schwinn et al., } \\
2016\end{array}$ \\
\hline & & & R2R3-MYB & $\begin{array}{l}\text { biosintesis } \\
\text { antosianin }\end{array}$ & $\begin{array}{l}\text { Schwinn et al., } \\
2016\end{array}$ \\
\hline & & & NFAM1 & $\begin{array}{l}\text { reseptor } \\
\text { imun }\end{array}$ & $\begin{array}{l}\text { Charron et al., } \\
2015\end{array}$ \\
\hline
\end{tabular}




\begin{tabular}{|c|c|c|c|c|c|}
\hline & & & GCLC gene & $\begin{array}{l}\text { pengkode GSH } \\
\text { (Reduced } \\
\text { glutathione) } \\
\text { sebagai } \\
\text { antioksidan, } \\
\text { mencegah } \\
\text { kerusakan protein, } \\
\text { lipid dan asam } \\
\text { nukleat }\end{array}$ & $\begin{array}{l}\text { Capasso, 2013; } \\
\text { Hiratmitsu et al., } \\
\text { 2015; Rodrigues } \\
\text { \& Percival, 2019; }\end{array}$ \\
\hline \multirow[t]{3}{*}{2} & \multirow[t]{3}{*}{$\begin{array}{l}\text { Andrographis } \\
\text { paniculata }\end{array}$} & \multirow[t]{3}{*}{ Sambiloto } & ApNAC1 & $\begin{array}{l}\text { antidislipidemik, } \\
\text { oksidasi LDL dan } \\
\text { aktivitas } \\
\text { antioksidan }\end{array}$ & Wang et al., 2017 \\
\hline & & & UFGT & produksi antosianin & $\begin{array}{l}\text { Wu et al., 2017; } \\
\text { Li et al., } 2019\end{array}$ \\
\hline & & & CCL & $\begin{array}{l}\text { induksi } \\
\text { imunostimulator }\end{array}$ & $\begin{array}{l}\text { Denzler et al, } \\
2010\end{array}$ \\
\hline \multirow[t]{2}{*}{3} & \multirow[t]{2}{*}{ Blumea balsamifera } & \multirow[t]{2}{*}{ Sembung } & CCL & $\begin{array}{l}\text { induksi } \\
\text { imunostimulator; } \\
\text { melindungi } \\
\text { hepatosit dari } \\
\text { peroksidasi lipid }\end{array}$ & Pu et al., 1998; \\
\hline & & & FPS & aktivitas katalitik & Pang et al., 2014 \\
\hline 4 & $\begin{array}{l}\text { Cinnamomum } \\
\text { burmannii }\end{array}$ & Kayu manis & GR1 & $\begin{array}{l}\text { peningkatan } \\
\text { aktivitas } \\
\text { fagositosis } \\
\text { makrofag }\end{array}$ & $\begin{array}{l}\text { Pratiwi et al., } \\
\text { 2015; Shin et al., } \\
2017\end{array}$ \\
\hline 5 & Citrus sinensis & Jeruk manis & CsCYT75B1 & $\begin{array}{l}\text { metabolisme } \\
\text { antioksidan } \\
\text { flavonoid }\end{array}$ & Rao et al., 2020 \\
\hline 6 & Cordyceps militaris & $\begin{array}{l}\text { Jamur } \\
\text { cordyceps }\end{array}$ & wc1 & regulasi transkripsi & $\begin{array}{l}\text { Kim et al., 2007; } \\
\text { Dong et al., 2012 }\end{array}$ \\
\hline 7 & Curcuma longa & Kunyit & $\begin{array}{l}\text { CURS1, } \\
\text { CURS2, } \\
\text { CURS3 }\end{array}$ & $\begin{array}{l}\text { Mengkatalisis } \\
\text { sintesis kurkumin } \\
\text { dengan } \\
\text { mengkondensasi } \\
\text { feruloyl-CoA } \\
\text { dengan diketida- } \\
\text { CoA dalam } \\
\text { biosintesis } \\
\text { kurkuminoid }\end{array}$ & $\begin{array}{l}\text { Sun et al., 2017; } \\
\text { Santhoshkumar } \\
\text { \& Yusuf, } 2020\end{array}$ \\
\hline 8 & $\begin{array}{l}\text { Curcuma } \\
\text { xanthorrhiza }\end{array}$ & Temulawak & $\begin{array}{l}\text { CURS1, } \\
\text { CURS2, } \\
\text { CURS3 }\end{array}$ & $\begin{array}{l}\text { Mengkatalisis } \\
\text { sintesis kurkumin } \\
\text { dengan } \\
\text { mengkondensasi } \\
\text { feruloyl-CoA } \\
\text { dengan diketida- } \\
\text { CoA dalam } \\
\text { biosintesis } \\
\text { kurkuminoid }\end{array}$ & Sun et al., 2017 \\
\hline 9 & $\begin{array}{l}\text { Cymbopogon } \\
\text { citratus }\end{array}$ & Sereh; Serai & MAPK & $\begin{array}{l}\text { menghambat } \\
\text { ekspresi iNOS }\end{array}$ & $\begin{array}{l}\text { Francisco et al., } \\
\text { 2011; Somparn et } \\
\text { al., } 2018\end{array}$ \\
\hline 10 & $\begin{array}{l}\text { Kaempferia } \\
\text { galanga }\end{array}$ & Kencur & psbA & $\begin{array}{ll}\text { regulasi } & \text { sistem } \\
\text { antioksidan } & \end{array}$ & $\begin{array}{l}\text { Techaprasan et } \\
\text { al., } 2010\end{array}$ \\
\hline
\end{tabular}




\begin{tabular}{|c|c|c|c|c|c|}
\hline 11 & Moringa oleifera & Kelor & psbA & $\begin{array}{l}\text { regulasi sistem } \\
\text { antioksidan }\end{array}$ & $\begin{array}{l}\text { Ramasetty et al., } \\
\text { 2016; Hassan et } \\
\text { al., } 2020\end{array}$ \\
\hline \multirow[t]{2}{*}{12} & Nigella sativa & Jintan hitam & psbA & $\begin{array}{l}\text { regulasi sistem } \\
\text { antioksidan }\end{array}$ & $\begin{array}{l}\text { Sudhir et al., } \\
2014\end{array}$ \\
\hline & & & MAPK & $\begin{array}{l}\text { menghambat } \\
\text { ekspresi iNOS }\end{array}$ & $\begin{array}{l}\text { Sudhir et al., } \\
2014\end{array}$ \\
\hline 13 & Phyllanthus niruri & Meniran hijau & psbA & $\begin{array}{ll}\text { regulasi } & \text { sistem } \\
\text { antioksidan } & \end{array}$ & $\begin{array}{l}\text { Srirama et al., } \\
2010\end{array}$ \\
\hline 14 & $\begin{array}{l}\text { Phyllanthus } \\
\text { urinaria }\end{array}$ & $\begin{array}{l}\text { Meniran } \\
\text { merah }\end{array}$ & psbA & $\begin{array}{l}\text { regulasi sistem } \\
\text { antioksidan }\end{array}$ & $\begin{array}{l}\text { Srirama et al., } \\
2010\end{array}$ \\
\hline 15 & Psidium guajava & Jambu biji & $\mathrm{psbA}$ & $\begin{array}{ll}\text { regulasi } & \text { sistem } \\
\text { antioksidan } & \end{array}$ & $\begin{array}{l}\text { Reatini et al., } \\
2018\end{array}$ \\
\hline 16 & $\begin{array}{l}\text { Syzygium } \\
\text { aromaticum }\end{array}$ & Cengkeh & psbA & $\begin{array}{ll}\text { regulasi } & \text { sistem } \\
\text { antioksidan } & \end{array}$ & $\begin{array}{l}\text { Roslim et al., } \\
2016\end{array}$ \\
\hline 17 & $\begin{array}{l}\text { Syzygium } \\
\text { polyanthum }\end{array}$ & Salam & psbA & $\begin{array}{ll}\text { regulasi } & \text { sistem } \\
\text { antioksidan } & \end{array}$ & $\begin{array}{l}\text { Roslim et al., } \\
2016\end{array}$ \\
\hline \multirow[t]{2}{*}{18} & Zingiber officinale & Jahe & CDPK & $\begin{array}{l}\text { pengikatan } \\
\text { kalsium; } \\
\text { imunogenisitas }\end{array}$ & Vivek et al., 2017 \\
\hline & & & psbA & $\begin{array}{ll}\text { regulasi } & \text { sistem } \\
\text { antioksidan } & \end{array}$ & $\begin{array}{l}\text { Sendanayake et } \\
\text { al., } 2017\end{array}$ \\
\hline
\end{tabular}

\section{KESIMPULAN}

Tanaman lokal Indonesia, baik wild type maupun introduksi, formulasi tunggal ataupun kombinasi, dalam bentuk jamu ataupun formula lainnya, telah terbukti secara turun temurun mampu bertindak sebagai imunomodulator, mencegah tindakan antagonis pada stres oksidatif, serta perannya dalam memerangi penyakit yang disebabkan oleh infeksi virus. Mekanisme aktivitas imunomodulasi terjadi terutama melalui stimulasi fagositosis, makrofag aktivasi, efek imunostimulan pada peritoneal makrofag, stimulasi sel limfoid dan lainnya. Meskipun demikian, tanaman lokal ini, jika akan diformulasikan sebagai obat COVID-19, harus telah melalui tahap uji klinis fase 3, sehingga dosis, mekanisme kerja obat, efektivitas, efek samping dan keamanan obat tersebut telah teruji, berada pada level pembuktian ilmiah tertinggi dan dapat dilepas di masyarakat.

\section{DAFTAR PUSTAKA}

Aziz, I. R. (2019). Kromosom tumbuhan sebagai marka genetik. Teknosains 13(2): 125-131.

Aziz, I. R. (2020). Variasi kromosom familia Rutaceae di Indonesia. Teknosains 14(1): 115-127.

Charron, C. S., Dawson, H. D., Albaugh, G. P., Solverson, P. M., Vinyard, B. T., Solano-Aguilar, G. I., \& Novotny, J. A. (2015). A single meal containing raw, crushed garlic influences expression of immunity-and cancer-related genes in whole blood of humans. The Journal of Nutrition, 145(11), 2448-2455.

Denzler, K. L., Waters, R., Jacobs, B. L., Rochon, Y., \& Langland, J. O. (2010). Regulation of inflammatory gene expression in PBMCs by immunostimulatory botanicals. PloS one, 5(9), e12561.

Dong, J. Z., Liu, M. R., Lei, C., Zheng, X. J., \& Wang, Y. (2012). Effects of selenium and light wavelengths on liquid culture of Cordyceps militaris Link. Applied biochemistry and biotechnology, 166(8), 2030-2036.

Francisco, V., Figueirinha, A., Neves, B. M., García-Rodríguez, C., Lopes, M. C., Cruz, M. T., \& Batista, M. T. (2011). Cymbopogon citratus as source of new and safe anti-inflammatory drugs: bio-guided assay using lipopolysaccharide-stimulated macrophages. Journal of Ethnopharmacology, 133(2), 818-827.

Hassan, F. A., Ismail, I. A., Mazrou, R., \& Hassan, M. (2020). Applicability of inter-simple sequence repeat (ISSR), start codon targeted (SCoT) markers and ITS2 gene sequencing for genetic diversity assessment in Moringa oleifera Lam. Journal of Applied Research on Medicinal and Aromatic 
Plants, 100256.

Hiramatsu, K., Tsuneyoshi, T., Ogawa, T., \& Morihara, N. (2016). Aged garlic extract enhances heme oxygenase-1 and glutamate-cysteine ligase modifier subunit expression via the nuclear factor erythroid 2-related factor 2-antioxidant response element signaling pathway in human endothelial cells. Nutrition Research, 36(2), 143-149.

Kim, K., Kim, H., Han, S., Kim, K., Kwon, J., \& Lee, S. (2007). Immunomodulatory effects of CMDB, the component of Cordyceps militaris mycelium, by the enhanced production of cytokines in macrophages (B64).

Li, Y., Li, X. L., Lai, C. J. S., Wang, R. S., Kang, L. P., Ma, T. \& Huang, L. Q. (2019). Functional characterization of three flavonoid glycosyltransferases from Andrographis paniculata. Royal Society open science, 6(6), 190150.

Pang, Y. X., Guan, L. L., Wu, L. F., Chen, Z. X., Wang, K., Xie, X. L., \& Jiang, Q. (2014). Cloning and sequence analysis of the Blumea balsamifera DC farnesyl diphosphate synthase gene. Genet. Mol. Res, 13, 9874-9882.

Pu H.L., Zhao J.H., Xu S.B., Hu Q. 1998. Protective actions of Blumea flavanones on primary cultured hepatocytes against lipid peroxidation. Chin. Trad. Herb. Drug. 2000;31:1113-1115.

Pratiwi, T. S., Putri, A., \& Murwani, S. (2015). The effect of Cinnamomum burmannii extract as an immunomodulator on the increase of GR-1 expressing IFN $\gamma$ and macrophage.

Ramasetty, B. T., Bajpe, S. N., Kadappa, S. K. K., Saini, R. K., Basavaraju, S. N., Ramachandra, K. K., \& Sripathy, P. H. (2016). Identification and genetic diversity analysis of Memecylon species using ISSR, RAPD and Gene-Based DNA barcoding tools. Electronic Journal of Biotechnology, 24, 1-8.

Rao, M. J., Xu, Y., Tang, X., Huang, Y., Liu, J., Deng, X., \& Xu, Q. (2020). CsCYT75B1, a citrus cytochrome $\mathrm{P} 450$ gene, is involved in accumulation of antioxidant flavonoids and induces drought tolerance in transgenic Arabidopsis. Antioxidants, 9(2), 161.

Reatini, B., de Lourdes Torres, M., Valdebenito, H., \& Vision, T. (2018). Complete plastome sequences of two Psidium species from the Galápagos Islands. F1000Research, 7.

Rodrigues, C., \& Percival, S. S. (2019). Immunomodulatory effects of glutathione, garlic derivatives, and hydrogen sulfide. Nutrients, 11(2), 295.

Roslim, D. I., Nurkhairani, P., \& Herman, E. R. (2016). Identification of durik-durik plant (Syzygium sp.) using the psbA-trnH intergenic spacer and ITS regions. TPGM, 3, 11-16.

Santhoshkumar, R., \& Yusuf, A. (2020). In silico structural modeling and analysis of physicochemical properties of curcumin synthase (CURS1, CURS2, and CURS3) proteins of Curcuma longa. Journal of Genetic Engineering and Biotechnology, 18(1), 1-9.

Sendanayake, L., Sylvester, T., De Silva, U. H. A. J., Dissanayake, D. R. R. P., Daundasekera, D. M. K. C., \& Sooriyapathirana, S. D. S. S. (2017). Consumer preference, antibacterial activity and genetic diversity of ginger (Zingiber officinale Roscoe) cultivars grown in Sri Lanka. Journal of Agricultural Sciences-Sri Lanka, 12(3).

Shin, W. Y., Shim, D. W., Kim, M. K., Sun, X., Koppula, S., Yu, S. H., \& Lee, K. H. (2017). Protective effects of Cinnamomum cassia (Lamaceae) against gout and septic responses via attenuation of inflammasome activation in experimental models. Journal of ethnopharmacology, 205, 173-177.

Somparn, N., Saenthaweeuk, S., Naowaboot, J., Thaeomor, A., \& Kukongviriyapan, V. (2018). Effect of lemongrass water extract supplementation on atherogenic index and antioxidant status in rats. Acta Pharmaceutica, 68(2), 185-197.

Srirama, R., Senthilkumar, U., Sreejayan, N., Ravikanth, G., Gurumurthy, B. R., Shivanna, M. B., \& Shaanker, R. U. (2010). Assessing species admixtures in raw drug trade of Phyllanthus, a hepatoprotective plant using molecular tools. Journal of ethnopharmacology, 130(2), 208-215.

Sudhir, S. P., Kumarappan, A., Vyas, L. K., Shrivastava, D., Deshmukh, P., \& Verma, H. N. (2016). Identification of Nigella sativa seed and its adulterants using DNA barcode marker. AJLS, 4(5), 118128.

Sun, W., Wang, S., Zhao, W., Wu, C., Guo, S., Gao, H., \& Chen, X. (2017). Chemical constituents and biological research on plants in the genus Curcuma. Critical reviews in food science and nutrition, 57(7), 1451-1523.

Techaprasan, J., Klinbunga, S., Ngamriabsakul, C., \& Jenjittikul, T. (2010). Genetic variation of Kaempferia (Zingiberaceae) in Thailand based on chloroplast DNA (psbA-trnH and petA-psbJ) sequences. Genetics and Molecular Research, 9(4), 1957-1973.

Umar, M. I., Asmawi, M. Z. B., Sadikun, A., Altaf, R., \& Iqbal, M. A. (2011). Phytochemistry and medicinal properties of Kaempferia galanga L.(Zingiberaceae) extracts. African Journal of Pharmacy and Pharmacology, 5(14), 1638-1647. 
Vivek, P. J., Resmi, M. S., Sreekumar, S., Sivakumar, K. C., Tuteja, N., \& Soniya, E. V. (2017). Calciumdependent protein kinase in ginger binds with Importin- $\alpha$ through its junction domain for nuclear localization, and further interacts with NAC transcription factor. Frontiers in plant science, 7, 1909.

Wang, J., Qi, M. D., Guo, J., Shen, Y., Lin, H. X., \& Huang, L. Q. (2017). Cloning, subcellular localization, and heterologous expression of ApNAC1 gene from Andrographis paniculata. China Journal of Chinese Materia Medica, 42(5), 890-895.

Wu, X., Gong, Q., Ni, X., Zhou, Y., \& Gao, Z. (2017). UFGT: the key enzyme associated with the petals variegation in Japanese apricot. Frontiers in plant science, 8, 108.

Zhao, J. H., Xu, S. B., Wang, Z. L., Lin, Y. C., \& Chen, R. L. (1998). Protective Actions of Blumea Flavanones on Primary Cultured Hepatocytes and Liver Subcellular Organelle against Lipid Peroxidation. Journal of Chinese Pharmaceutical Sciences, 7, 152-156. 